\title{
WAYS OF ACHIEVING RELIGIOUS AND MORAL EDUCATION THROUGH COMBINED ACTIONS OF FAMILY AND SCHOOL ACTORS: A MARKETING RESEARCH IN THE NORTH-EASTERN REGION OF ROMANIA
}

\author{
Ghinea Adrian Ciprian \\ Trannsilvanya University of Brașov \\ ghinea.adrian.ciprian.@unitbv.ro
}

\begin{abstract}
This research is based on the PACE recommendation and in this paper we will showcase some of the results. Our main purpose was to describe and analyse possibilities to achieve a moral and religious education by both family and school actors, as well as to come up with an inventory of suggestions for the improvement of this two-fold type of education. For this article we will only focus on a supportive objective, namely identifying the state-of-fact of religious and moral education in the North-Eastern region of Romania, more specifically the item concerning the effectiveness of religion and the belief that it provides answers to some problematical issues in the lives of the subjects selected for the study.
\end{abstract}

\section{Keywords}

religious education, christian religion, moral beliefs, etics, religious pluralism, marketing research

\section{JEL Classification}

M39, Z12, I21

\section{Introduction}

In the pedagogy textbooks edited after 1989, religious education has regained its rights in a gradual manner (Leach \& Moon, 1972). In exchange, the aspect of moral education has remained a constant presence in textbooks, and the approach has been rather similar from one author to another. Should we remain faithfull to the christian epitome, we know why and how to deal with teaching religion, but we don't know for sure wirh what effects. For many people, it is necessary to be a religious person in order to be a moral person. Religion is regarded as a mediator of their morality, so, losing one of these aspects entails the loss, partially or entirely or temporarily or definetely, of the other. Some people, who have attended religion classes before 1989 will forever have this memory imprinted in their daily existence; others will have rather vague notions which will not badger them, whereas others will reject the religious outlook on the world, becoming self-sworn atheists. Of course, there will be those who will question, at some point, their religious beliefs or, out of pure social conformism, will formally uphold the rules of the confession they belong to, leaving the undecided, who, with no systematic religious education, will seek their own path towards the ultimate values, out of accomplished aspirations or confirmed deceptions. Nonetheless, the spiritual guidelines of education reflected in the pedagogical process are clearly demarcated, of course in a relative manner.

In a careful planning of didactic principles suitable for Christian religion, Magdalena Dumitrana identifies six such spiritual principles (Dumitrana, 2007). Three of them are 
principles of christian education (Opoku et al., 2006; Wilhoit \& Ryken, 1988): 1) ecclesiastical centricity principle; 2) the christian conception of the child principle and 3) all religious education is to be done within a centripet orientation towards Jesus Christ, as Divine and human alike. Other three principles (Alexander, 2003) are directly connected to religious education and teaching, namely 4) the constitution of the christian character, 5) the specific purpose and means of religion: it addresses predominantly to the affect, as it is a teaching which is not taught, but rather shared, or imparted, since the teacher plays the role of a spiritual mentor and the classroom becomes a small ecclesia; 6) the ethical-moral character of education, according to which christian religion undertakes from moral education the method to mould moral beliefs and behaviors and, in return, it bestows moral education the ideological content of the ethics necessary to be nurtured in school, that is christian morals.

It is believed that there are at least four reasons for strengthening the knowledge of religious facts in the public education system across Europe: 1) fighting religious illiteracy; 2) seeking answers to the challenges brought by democratic and religious pluralism; 3) counteracting the drift caused by the relativism sourced in the collapse of all major ideologies; 4) educating with the purpose of better living in the polis and of respect owed to the other (Mathieu \& Willaime, 2005).

The recommendation to strengthen religious education in public school (Powers, 2008) sums up a series of contradictions and unravels the reasons for which religious education system, although margianl in the curriculum, holds a symbolic stake for both state and society. On the one hand, there is ample recognition for the part played by moral beliefs and convictions in identity formation and social action drive. On the other hand, the tendency in european education is to undermine religious education on account of school education purposes, such as deconfessionalization, noncatechistic schooling and opening-up to a pluralism of interpretations (Cogill, 2008). Acknowledging the public mission of religions within the learning planning (in the sense of a Bildungsroman) is not equivalent to a homo religiosus plea. Because, beyond helping the child develop and justify his/her own options and cultivate an autonomous vision about the world and the way things exist, in general, the focus is not solely on a spirituality infusion in school, in other words the consciousness of faith (Scrima, 2011), but also on stregthening the modern and postmodern values' system. No matter how slender is the standpoint of authorities towards modern pedagogy, which guides but does not constrain (similar to the lectio divina of Origen of Alexandria (Keator, 2017)), it does not provide any account on the contradictions and ambivalence between the socio-cultural, political and educational options which exist when dealing with moralreligious education. Therefore, "Religion and democracy" Recommendation of the European Council emphasises "teaching about religions as sets of values towards which young people must develop a discerning approach, within the framework of education on ethics and democratic citizenship"(European Council Parliamentary Assembly, 1999:2). A critical review of a religious fact entails either to accept or to reject, in an informed manner (Hull, 2004), religious values, but can also lead to an emptiness of meaning or a backwards attestation of the matter of the Divine. The Reccomendation also makes refference to the problematic status of religion, as a study discipline in public schooling (Watkins \& Mortimer, 1999), given the fact that human rights and children rights represent the educational ethics of modern contemporary times.

\section{Methodological framing}

Our sample of social actors consisted of high-school pupils, parents and teachers from 24 high-schools in the North-Eastern region of Romania, out of which we were able to apply a questionnaire to 120 high-school pupils, 120 parents and 120 teachers, during 
January - February 2017. Unfortunately, the sample may not be considered representative for the targeted population, since the subjects were selected based on their accept and availability to respond to th questionnaire. The questionnaire applied contained items concerning the stated and the actual importance of religious faith, the trust in religious teachings and praxis, how various religious educational activities are implemented in schools and how different actors contribute or not to the religious education of pupils. Furthermore, there were included some items concerning the presence of religious symbols in schools, the place and role of religion in school and whether evaluation is done in religious classes in schools. Out of the total of four statistical hypothesis defined for this research, we have chosen to present the results obtained for the second, which is $\mathrm{H} 0$ over $50 \%$ of the respondents believe that religion offers adequate answers to the moral issues of society at large.

\section{Results and discutions}

Trust in religion is not limited to a mere doctrinal adherence; the depth of religious feelings is highly conditioned by its capacity to operate both in the interpersonal and social relations, as well as in the spiritual experiences realm and by the possibility to suggest solutions to the difficulties and problems of the individual and of society. When asked the question How much do you trust the religious teachings of your confession? $61 \%$ of the students questioned indicated a high level of trust, whereas one third indicated a moderate level of trust (see Table 1).

Table 1. Distribution of answers for the question How much do you trust the religious teachings of your confession?

\begin{tabular}{|l|l|c|c|c|c|c|}
\hline \multicolumn{2}{|l|}{ Trust } & High & Medium & Low & $\begin{array}{c}\text { Non } \\
\text { existant }\end{array}$ & $\begin{array}{c}\text { No } \\
\text { Answer }\end{array}$ \\
\hline Scores & & 3 & 2 & 1 & 0 & \\
\hline \multirow{2}{*}{$\begin{array}{l}\text { Living } \\
\text { Environment }\end{array}$} & Rural & $65,8 \%$ & $27,7 \%$ & $4,1 \%$ & $1,3 \%$ & $1,1 \%$ \\
\cline { 2 - 7 } Age & Urban & $56,6 \%$ & $35,9 \%$ & $4,9 \%$ & $2,1 \%$ & $0,5 \%$ \\
\cline { 2 - 7 } & under 15 & $74,4 \%$ & $9,3 \%$ & $2,3 \%$ & $7,0 \%$ & $7,0 \%$ \\
\cline { 2 - 7 } & $15-16$ & $61,1 \%$ & $32,9 \%$ & $4,1 \%$ & $1,3 \%$ & $0,7 \%$ \\
\cline { 2 - 7 } & $16-18$ & $60,9 \%$ & $32,1 \%$ & $4,7 \%$ & $1,5 \%$ & $0,7 \%$ \\
\hline \multirow{3}{*}{ Gender } & Male & $52,9 \%$ & $37,0 \%$ & $6,8 \%$ & $2,7 \%$ & $0,6 \%$ \\
\cline { 2 - 7 } & Female & $66,7 \%$ & $28,6 \%$ & $2,9 \%$ & $0,8 \%$ & $1,0 \%$ \\
\hline Total & & $61,0 \%$ & $32,1 \%$ & $4,4 \%$ & $1,6 \%$ & $1,0 \%$ \\
\hline
\end{tabular}

Those with the highest level of trust are the young people aged under 15 years $(74,4 \%)$, followed by the $17-18$ age sector $(60,1 \%)$. Male respondents $(52,9 \%)$ and students of both genders from both living environments $(56,6 \%)$ are situated in the lowest rank. When corroborating these observations with the data obtained regarding the importance given to religious beliefs, we observed that even though most of the high-school students $(85,7 \%)$ value religious belief in a highest manner, less then two thirds state a level of trust equal in force, whereas one third declare a moderate trust level, a fact which may indicate a misalignment with their own system of convictions.

Therefore, we may assert that for an important segment of young population, the importance bestowed to religion is much higher than the trust in the doctrine itself, these young people distancing themselves in a critical manner from the traditional teachings. Lacking such an important characteristic, namely a total adherence to dogmatic teachings, we may consider that their devoutness may relate more to insufficiently defined interests towards the religious phenomenon and to a diffused aspiration towards the Sacred. We may also presume that these tendencies will compel 
them to extend their search towards other religions or spiritual manifestations, from which they will extract eclectic ideas, but much more resonant to their own aspirations and beliefs. The total value of $61 \%$ from Table 1 is evidence to the fact that only this percentage is fully convinced of the doctrinal truths, therefore we included an item in the questionnaire targeted towards the four functions fulfilled by religion (see Table 2): a function of purpose (Religion offers answers regarding the meaning of life); a function of ethics (Religion makes the faithfull to become more ethical); a function of affect, which induces a soothing reaction or a reduction of anxiety (Religion brings confort and hope to the faithfull) and a function of social cohesion (Religion brings people together, making them more sympathetic).

Table 2 Distribution of answers to the question How much would you agree with the following statements?

\begin{tabular}{|c|c|c|c|c|c|c|c|c|}
\hline TOTAL & High & Medium & Low & $\begin{array}{c}\text { Not } \\
\text { at all }\end{array}$ & $\begin{array}{c}\text { I don't } \\
\text { know }\end{array}$ & NR & $\begin{array}{c}\text { Weig } \\
\text { hted } \\
\text { Avera } \\
\text { ge }\end{array}$ & Rank \\
\hline Scores & 3 & 2 & 1 & 0 & & & & \\
\hline $\begin{array}{c}\text { 1) Religion } \\
\text { offers answers } \\
\text { regarding the } \\
\text { meaning of } \\
\text { life }\end{array}$ & $46,8 \%$ & $30,5 \%$ & $10,2 \%$ & $\begin{array}{c}3,5 \\
\%\end{array}$ & $3,2 \%$ & $5,7 \%$ & 2,246 & II. \\
\hline $\begin{array}{c}\text { 2) Religion } \\
\text { makes the } \\
\text { faithfull to } \\
\text { become more } \\
\text { ethical }\end{array}$ & $42,9 \%$ & $29,5 \%$ & $10,3 \%$ & $\begin{array}{c}2,8 \\
\%\end{array}$ & $6,0 \%$ & $8,5 \%$ & 2,162 & IV. \\
\hline $\begin{array}{c}\text { 3) Religion } \\
\text { brings confort } \\
\text { and hope to } \\
\text { the faithfull }\end{array}$ & $65,3 \%$ & $17,0 \%$ & $6,0 \%$ & $\begin{array}{c}1,3 \\
\%\end{array}$ & $3,4 \%$ & $6,9 \%$ & 2,535 & I. \\
\hline $\begin{array}{c}4 \text { Religion } \\
\text { brings people } \\
\text { together, } \\
\text { making them } \\
\text { more } \\
\text { sympathetic }\end{array}$ & $47,5 \%$ & $24,2 \%$ & $13,0 \%$ & 3,0 & $4,3 \%$ & $7,9 \%$ & 2,216 & III \\
\hline
\end{tabular}

The answers, based on the weighted average, reveal the fact that $65.3 \%$ place the function of affect on first place (Religion brings confort and hope to the faithfull) whereas all the remaining functions present similar values $(46.8 \%, 42.9 \%$ and $47.5 \%)$, therefore prooving a certain inhibition towards the possibility that religion may offer answers regarding the meaning of life or that it may bring people together.

For the function of ethics, we may posit that, even though religion prescribes the rules of conduct for interpersonal reltions, this does not imply that they are necessarily followed in day-to-day living. Or, regulating the moral conduct on a behavioral level is projected, in the external manifestation of interpersonal rapport, through a demeanour constantly guided by the prescriptions derived from religion itself. Even so, for the question Is religious belief a benchmark for your decision making or choice of behavior? only $23.7 \%$ of high-school respondents stated that they always regulate their 
conduct based on religious canons. It may be assumed that, when dealing with daily living challenges, young people do not always find in their confession an effective way to act, in accordance also with the behavioral norms as well.

\section{Conclusions and further research}

Our purpose In this article we have described and analyzed the possibilities of achieving a moral and religious education by both family and school actors and we have made an inventory of suggestions for improving this type of education twice. During the research we identified the current situation of religious and moral education in the northeastern region of Romania, focusing on the effectiveness of religion and faith.

From the results presented in a limited manner in this paper, we may pinpoint three future research directions:

- since affect was indicated as the highest function of religion, it may be of interest to analyse the connection between internalized affect and the inhibition manifested externally, namely why is there a disconnect between a confort and hope brought within the faithfull and the external manifestation of this confort, which is clearly not perceived as being linked to purpose, ethics or social cohesion;

- should we define the lack of an effective way to act as a lost in translation locus of the younger generation, it may useful to dwelve on various, and probably more effective ways to depict the all-encompasing truths embedded in religious teachings, such as social media or even digital discourse manifestations;

- creating more windows of opportunity and of dialogue with the younger generations to better equip the church (Malory \& Smith, 2001) in responding to the younger generations' aspirations and beliefs. This may offer rich conversations with the younger generations, in the sense of aligning their perception with what is already encoded in the Christian texts.

\section{References}

Alexander, R., (2003). Still No Pedagogy? Principle, Pragmatism and Compliance in Primary Education, Cambridge: University Of Cambridge.

Cogill, J. (2008). Primary Teachers' Interactive Whiteboard Practice across One Year: Changes in Pedagogy and Influencing Factors. King's College University of London.

Dumitrana, M. (2007), Didactica Crestina. Bucuresti: V\&I Integral.

European Council Parliamentary Assembly (1999). PACE - Recommendation 1396 (1999) Religion and democracy.

Hull, J. M., (2004). 'Practical Theology and Religious Education in a Pluralist Europe', London, British Journal of Religious Education Vol. 26, No. 1.

Keator, M. (2017), Lectio Divina as Contemplative Pedagogy: Re-appropriating Monastic Practice for the Humanities. Boca Rato, USA, Routledge.

Leach, J. and Moon, B. (1999). Learners and Pedagogy, London: P.C.P.

Mallory, Sue and Smith, Brad, (2001). The Equipping Church. Grand Rapids, MI. Zondervan.

Mathieu, S., \& Willaime, J.-P. (2005). Des maîtres et des dieux: Écoles et religions en Europe. Paris, Ed. Belin.

Opoku, John \& Addai-Mensah, Peter \& Manu, Eric. (2014). Realization of the nature and role of christian education in modern pedagogy. British Journal of Education. 2.

Powers, Bruce P., Ed./Comp. (2008). Christian Education Handbook. Nashville. Broadman Press.

Scrima, A. (2011). Functia Critica A Credintei. București, Ed. Humanitas. 
WAYS OF ACHIEVING RELIGIOUS AND MORAL EDUCATION THROUGH COMBINED ACTIONS OF FAMILY AND SCHOOL ACTORS: A MARKETING RESEARCH IN THE NORTH-EASTERN REGION OF ROMANIA

Watkins, C. and Mortimer, P. (1999). 'Pedagogy: What do we know?' In: Mortimer, P. (Ed), Understanding Pedagogy and Its Impact on Teaching, London: Chapman. Wilhoit, Jim and Ryken, Leland. (1988). Effective Bible Teaching. Grand Rapids, MI. Baker Book House. 